CONTRIBUTIONS FROM THE

$r .4$ no. 2 MUSEUM OF THE AMERICAN INDIAN

HEYE FOUNDATION

Volume IV, Number 2

CERTAIN ARCHAEOLOGICAL INVES-

TIGATIONS IN TRINIDAD, BRITISH WEST INDIES

BY

THEODOOR DE BOOY

Reprinted from the American Anthropologist (N.s.), Vol. I9, No. 4,

Jctober-December, I9I7

NEW YORK

MUSEUM OF THE AMERICAN INDIAN

HEYE FOUNDATION

1918

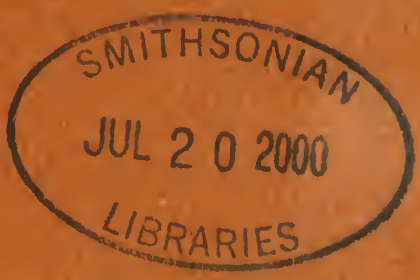





\section{CERTAIN ARCHAEOLOGICAL INVESTIGATIONS IN TRINIDAD, BRITISH WEST INDIES ${ }^{1}$}

By THEODOOR DE BOOY

\section{INTRODUCTION}

$\mathrm{A}^{\mathrm{s}}$

$\mathrm{S}$ this paper is intended solely to put on record the excavations made by the writer and some of the resulting specimens, it does not seem advisable to go extensively into the previous literature existing on the archaeology of Trinidad. Neither does the writer consider it imperative to illustrate many of the artifacts found or to discuss them at length, he being more desirous of explaining the conditions under which the objects were found. Some three thousand specimens in all were sent to the Museum of the American Indian from Trinidad during the four months that the writer worked on this island and it would require a bulky monograph to thoroughly describe each separate specimen.

Dr. J. Walter Fewkes, of the United States Bureau of American Ethnology, made a survey of some of the shell-heaps at Erin Bay on the south coast of Trinidad for the Museum of the American Indian (Heye Foundation) (which at that time was known as the Heye Museum), ${ }^{2}$ and the Reverend Thomas Huckerby, who was then

After an archaeological exploration of the island of Margarita off the north coast of Venezuela from February to May, I9I5, described by the writer in a previous paper, (Booy, Theodoor de, "Certain Archeological Notes on the Island of Margarita (Venezuela)," Contributions from the Museum of the American Indian (Heye Foundation), Vol. II, Number 5), a certain amount of work was done in the British island of Trinidad, I 20 miles to the eastward of Margarita and the writer remained here from May until September of the same year. The local government of this latter island and a number of the residents and landowners were of great assistance to the writer in his archaeological work and he wishes to take this opportunity to tender the thanks of both the Museum of the American Indian (Heye Foundation) and of himself to Paul Urich, Esq., of the St. Bernard Estate near Cape Mayaro, on whose property the greater part of the work was done, to Mrs. Paul Urich for her unfailing kindness and hospitality, to Carl Boos, Esq., of Port-of-Spain, for his aid in innumerable matters and to the officials of the Royal Victoria Institute of Port-of-Spain.

${ }^{2}$ Fewkes, J. Walter, "Prehistoric Objects from a Shell-heap at Erin Bay, Trinidad," American Anthropologist (N. S.), vol. I6 (April-June, r9r4), pages 200-220. 
living in Trinidad, conducted some excavations on the St. Bernard estate near Cape Mayaro, the results of which excavations are now in the Museum of the American Indian (Heye Foundation) as are the specimens obtained by Dr. Fewkes at Erin Bay. The Huckerby specimens proved to be somewhat different from those collected by

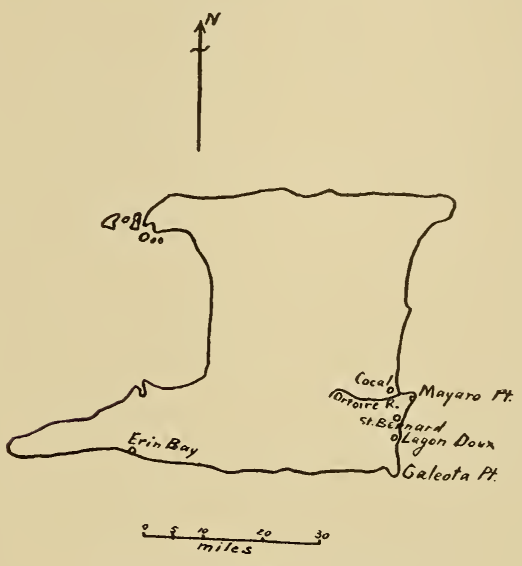

FIG. 6I.-Map of Trinidad.

Dr. Fewkes and as Mr. Huckerby obtained only comparatively few objects, the writer decided to make a thorough investigation of the remains on the east coast of Trinidad, to see if a different culture could have existed there. On arrival at Por t-of-S pain, therefore, he was introduced to Mr. Paul Urich, who owns extensive plantations on the east coast of the island near Cape Mayaro (see map, fig. 6I) and received a cordial invitation to come there and to excavate on the St. Bernard property. It was on this same property that Mr. Huckerby had made a number of somewhat superficial investigations and had collected those specimens that had first drawn the writer's attention to a difference between the east coast and the south coast pottery.

The shell-deposits in which the pottery and other pre-Columbian objects were found are situated on the St. Bernard property, about one and one half miles south of Cape Mayaro and one fourth of a mile inland from the sea beach. It is likely that in pre-Columbian times these deposits were a far greater distance from the sea, possibly from three fourths of a mile to a mile. The tides on this part of the east coast of Trinidad are so strong that the seashore is constantly being pushed further inland; on riding along the shore, one sees stumps of cocoanut trees on the beach as mute evidence of groves that existed before the sea swept them away and a number of the palms overhang the beach itself with part of the roots exposed by the action of the waves. After each severe easterly storm, a 

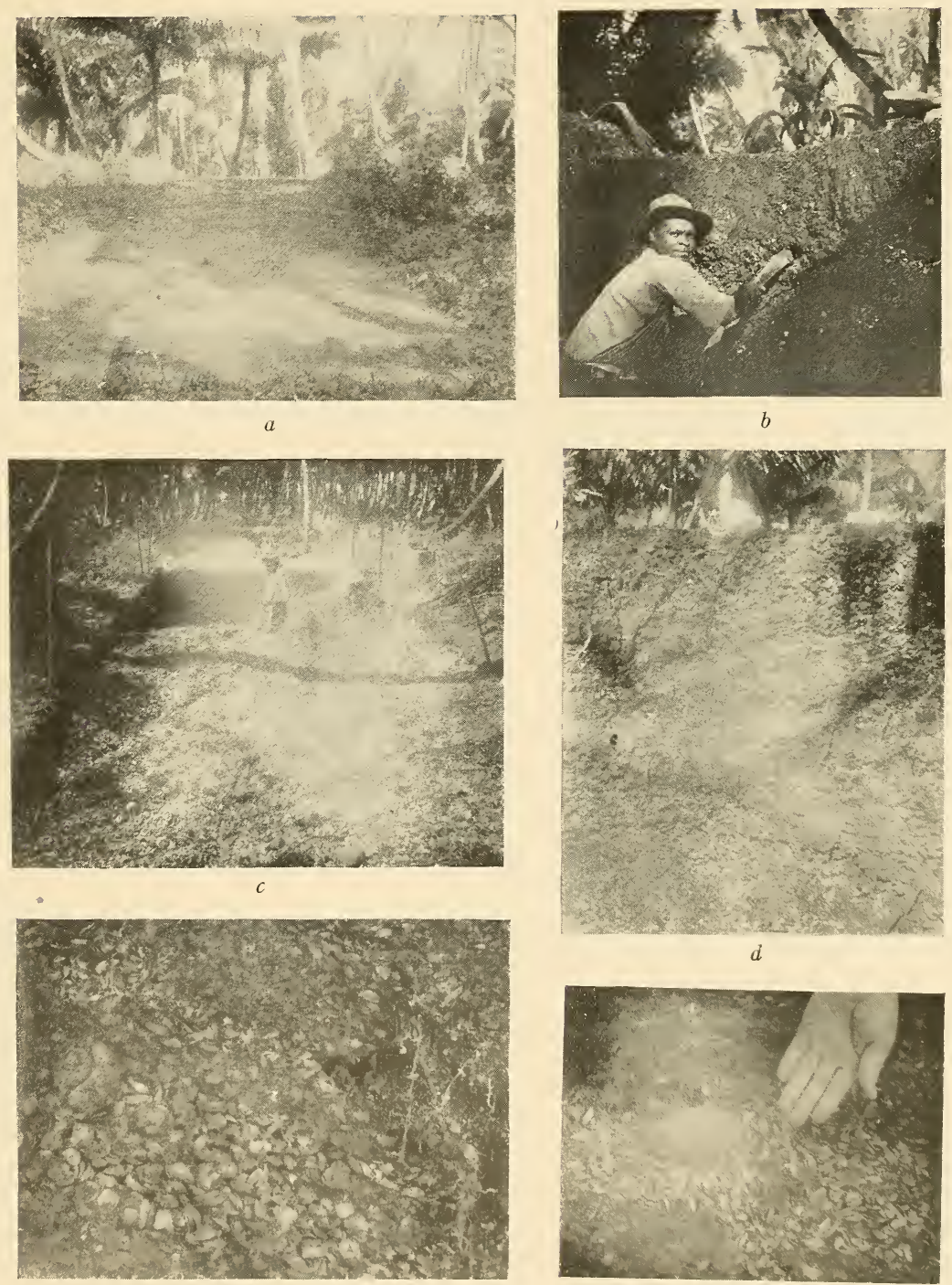

$e$

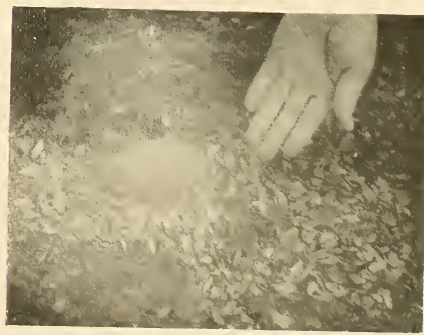

EXCAVATIONS IN PROCESS IN ST. BERNARD MIDDENS, TRINIDAD

$a$. Clearing ground for trench. $b$. Diluvial deposit covering shell-heaps. $c$. Trench, Io feet wide, through hummock. $d$. Shell- and ash-layer in deposit. $e$. Ash-layer in deposit mnderneath layer of tivela mactroides. $f$. Sherd in silu in shell-layer. 

number of the trees fall, owing to the fact that the waves have washed away the soil and sand that supported the roots. The writer has been assured by competent geologists that probably not more than five hundred years ago, the shore ran in a straight line from Mayaro Point to Galeota Point, which would place the St. Bernard middens fully a mile inland.

The St. Bernard deposits cover an area of possibly from six to eight acres of land and lie in what now is a cocoanut grove and what some sixty years ago was a field of sugarcane. Since the abandonment of the village site by the aboriginal inhabitants and the subsequent sugarcane and cocoanut cultivation, the shellheaps have become covered with a diluvial deposit from one to two feet deep, so that the individual middens can hardly be recognized amid the light undergrowth that covers the soil. The writer was not able to determine the number of the individual hummocks for this reason and had to make his excavations in those places where test holes proved the deposits to be the thickest.

The first process in the excavations was to clear the slope of a hummock of the small brush and to run the lines of a future trench in such a manner that they avoided the cocoanut trees as much as possible. A clearance three feet in diameter had to be given to each tree in order to avoid damaging the roots too much. The accompanying illustration, plate III, $a$ gives one an idea of the largest hummock found on the St. Bernard estate which hummock was about ten feet high. The roots of the cocoanut trees interfered to a great extent with the excavations and are no doubt responsible for a considerable amount of breakage of the pottery objects found; also, the writer had to watch the laborers constantly to prevent their chopping off the roots too near to the trees, in which event a number of the palms would have been damaged beyond recovery. It generally was possible to make the trenches from ten to twelve feet wide and to excavate in such a manner that the shells and the soil filled the trench up again back of the laborers, leaving eight feet of the bottom of the trench cleared between the cut and the refilled trench. An excavation of this sort can be seen in plate III, $c$. 
The deposits themselves ranged in depth from seven feet to less than a foot and, as has been stated, were covered with from one to two feet of diluvial deposit. Practically no objects were found in the diluvial covering, with the exception of small sherds and shells that had been moved towards the surface at those times when the soil was disturbed in cultivation. This diluvial deposit can be clearly seen in plate III, $b$ and the first shell-layer under the dilurium is indicated by the laborer with his cutlass. Under the diluvial deposit came a series of clearly defined shell- and ashlayers showing the various periods of occupation of the village site. These lavers reached a large number where the deposits were seven feet thick and, as is shown in plate III, $d$, did not run parallel to the surface of the ground nor did they run parallel the one to the other. It would seem as if the aborigines built their refuse-heaps in a different spot on each successive occupation, although on the same village site, which practice would account for the various angles at which the layers ran. The artifacts were most generally found in the darker ash-layers shown in the illustration. Fairly- large fragments of charcoal were met with in the ash-layers and also pieces of pitch or manjak. These latter pieces probably came from the deposits that are found in various places on the east coast of Trinidad. It may be mentioned that the writer excavated a number of pottery fragments that showed signs of having been covered with this pitch; whether these fragments are of ressels in which the pitch was melted or whether the pitch had been put in the ressels to mend them, the writer is not prepared to state definitely, although in one or two instances he is almost positire that ressels had been so restored.

The shells in the shell-layers of the deposits were not mixed with soil and were comparatively clean. The ash-layers, on the other hand, were a sticky gray mass in which bone fragments, shells, charcoal and ashes were mixed. A typical ash-layer is shown in plate III, $e$ and underneath this layer can be seen a shell-layer composed of the shells of Tirela mactroides. The writer estimated that some to per cent. of the shells found in the St. Bernard deposits were of this latter species and some 58 per cent. of the 
Donax variabilis, which is the small shell shown in plate III, $f$. In this illustration also is shown a large fragment of a pottery vessel in situ. The Donax variabilis is locally known as the "chip-chip" shell and is found in enormous numbers on the beach at certain times of the year. The present-day inhabitants gather these and make them into the locally renowned "chip-chip soup," a somewhat sandy delicacy greatly esteemed by the negro population. The aborigines undoubtedly used the chip-chip as one of their staple articles of diet and at those seasons when they were not found in abundance probably used the Tivela mactroides, which is found mostly on the sea beach north of Cape Mayaro and, strange to say, is hardly met with on the beach south of the Cape. Incidentally, the writer is of the opinion that the shells of this latter species were "steamed" in order to prepare them for food, in contrast to the chip-chip shells, which were boiled. He bases his contention on the fact that where the chip-chip shells are found clean and white in the deposits, the Tivela mactroides shells were always found in a blackened condition. The chip-chip shells are so small that "steaming" them would be out of the question and the only way they can be prepared is to cook them so as to detach the small animal from its shell.

The writer is indebted to Mr. L. P. Gratacap, of the American Museum of Natural History, for the identification of the shells found in the deposits and to Dr. F. A. Lucas, the director of the same institution, for the identification of some of the bones.

The sea shells found in the St. Bernard kitchen-middens are the following:

Donax variabilis Say. -58 per cent.

Tivela mactroides Born.-40 per cent.

Ostrea cristata Born.

Pecten nodosum Linnaeus.

Scarpharca brasiliana Lamarck.

Lucina jamaicensis Lamarck.

Tellina interrupta Wood.

Labiosa canaliculata Say.

Dione veneris Argenville.

Melongena melongena Linnaeus.

Melongena morio Linnaeus. 
Strombus gigas Linnaeus.

Cypraea exanthema Linnaeus.

Astralium tuber Linnaeus.

Of fresh-water shells the following two varieties were found:

Ampullaria spixii Orbiguy.

Ampullaria cornu-sarietis Linnaeus.

One species of land-shell was found, that of the

Strophocheilus (Borus) oblongus Miller.

Besides these shells, a great number of fragments of madrepore coral were found in the deposits.

Of the bones, those that were identified were of the

Deer-Odocoileus gymnotis, of the

Collared peccary-Pecari angulatus angulatus and of the

Green turtle-Chelone mydas.

A number of bones were found of fishes and of some of the smaller mammals which were not identifiable. The St. Bernard deposits also produced a number of crab carapaces and claws and the large crabs found in this neighborhood are even today a favorite food of the inhabitants.

Unlike on the island of Margarita, no split human bones were found in the shell-heaps. The writer found two burials in the middens and the skeletons were found in such a bunched-up position that he came to the conclusion that the dead had been placed in a contracted position, and probably had been buried in their house site. This was not an uncommon practice of the Antilleans and it was usual to afterwards abandon the house and move to another spot. ${ }^{1}$ The two burials in question were found in a layer of sea sand under and above which were the usual shell- and ashlayers, evidence that the village site had been used before and after the deaths had taken place. It was not possible to preserve the brittle bones, but, judging from the skull fragments, the hears had been artificially flattened. The writer was especially struck by the appearance of the teeth of both skeletons: they were quite

\footnotetext{
1 Fewkes, J. Walter, "Relations of Aboriginal Culture and Environment in the Lesser Antilles," Bulletin of the American Geographical Society, vol. XIvr, no. 9 (Sep. tember, I9I4), page 673 .
} 
ground down, as in the case of very aged persons, yet did not show a trace of decay.

Some six miles to the south of the St. Bernard estate, on a property called Lagon Doux, also belonging to Mr. Paul Urich, the writer was shown another shell deposit on the southeastern slope of a hill about four hundred feet high and lying a mile inland from the sea beach. These deposits, however, were not thick enough to warrant the conducting of excavations and, due to centuries of rainfall, the middens had been washed down the slope of the hill and distributed over a large area with a resulting breaking-up of the objects into small fragments. A number of shallow deposits were also found by the writer on the extremity of Cape Mayaro, some three hundred feet above sea level. A cursory examination was enough to show that the deposits were too shallow to produce objects that would make excavating worth while.

On the Cocal property, about four miles to the north of Cape Mayaro, the writer discovered an isolated shell-heap, twelve feet high with a diameter of about fifty-five feet, composed almost exclusively of the shells of Tivela mactroides. This shell-heap presented a curious problem to the investigator, as its height and isolation made it prominent in the landscape. Shallow shelldeposits were found bordering it on all sides but, as in the previously cited cases, the writer did not consider it worth while to excavate in any of these, although test holes and small sherds on the surface of the ground proved conclusively that an Indian occupation had existed here. A ten-foot trench was dug through the isolated mound north and south and another ten-foot trench east and west, forming a cross over the summit of the mound. While a large number of small pottery sherds had been found on the surface of the ground in all directions from the mound, not a single sherd was found in the mound itself. Three hammerstones were found and two small pieces of rock-crystal, the latter evidently having been brought there from the northern mountain range of the island of Trinidad, the only place on the island where these crystals are found according to reputable local geologists. It will be seen, therefore, that this isolated mound, exclusively composed of shells, 
in which no ashes, or bones and practically no artifacts were found, presents a curious problem compared to the other shell-deposits on the east coast of Trinidad, a problem which the writer is not able to solve.

\section{Archaeological Results from the Excavations}

The most typical of all the various pottery vessels found in the St. Bernard middens is a shallow bowl form with a broad angular rim. It is safe to say that of the sherds found, at least 75 per cent. indicated that they belonged originally to a vessel of this type and this form, therefore, in its many variations, can be taken as being typical of the east coast region of Trinidad.

The simplest form of vessels of this type is the small bowl $a$ shown on plate IV. This little dish has a main diameter of $7 \frac{1}{4}$ inches and an inside diameter of $5 \frac{1}{2}$ inches and its height is $1 \frac{7}{8}$ inches. The angular rim itself is $\frac{7}{8}$ inch wide and was covered with a red paint by the potter on the upper surface. The body of the bowl is of a buff color and the paint on the rim was probably applied after the firing of the vessel and can easily be washed off. The pottery is $\frac{3}{8}$ inch thick. It must be noted that in all vessels of this type the height of the vessel is from $\frac{1}{3}$ to $\frac{1}{4}$ of its outside diameter. The base of this type of vessel is invariably flat but, judging from sherds found, was in some instances extended into a circular stand to give added stability to the vessel. While the specimen illustrated has a painted rim, a large number of bowls of this type were found of which the rim had not been painted and was of the same color as the vessel proper. This then is the simplest form of the type under discussion.

The next addition to the decoration of this type of bowls are the handles and an astonishing variety of forms of the latter were met with in the St. Bernard deposits. In plate $\mathrm{V}, a$, can be seen one of these bowls to which has been added two loop handles of a somewhat elaborate pattern. Outside of this addition the bowl does not differ materially from the one previously described, excepting that it is far larger. The diameter of the bowl itself is 12 inches and its depth 4 inches. The thickness of the pottery is $\frac{3}{8}$ inch and the ware is buff colored. 

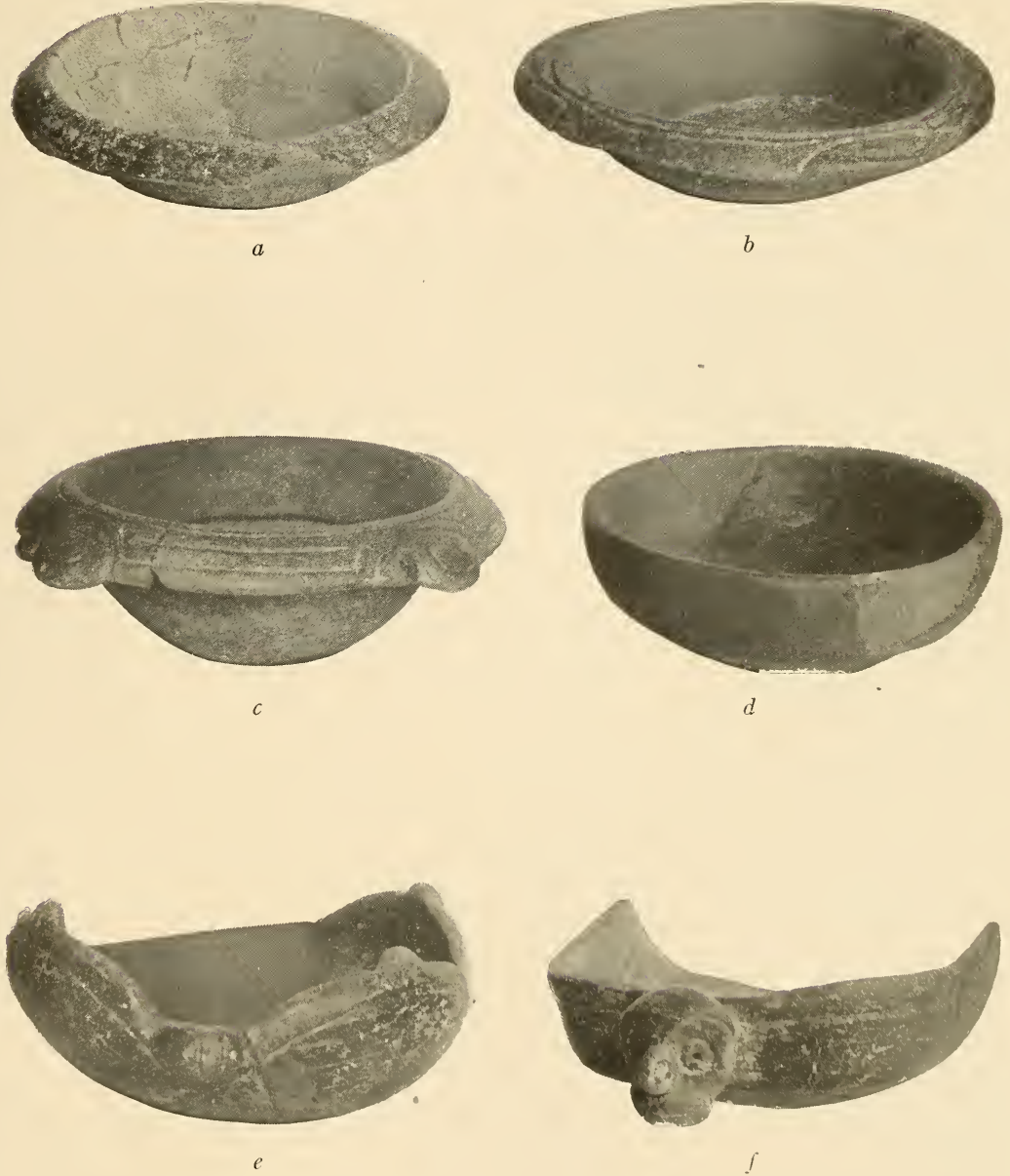

POTTERY VESSELS FROM ST. BERNARD MIDDENS 

Then again, the potter took the plain bowl of this type and added a design of incised lines to the rim. The simplest form of this were from one to six concentric lines running around the rim. In plate IV, $b$, can be seen a small bowl to which the potter, by way of decoration, has added two incised lines running concentrically around the rim and four extra semi-circular lines from the outside incised lines to the outside of the rim. The main diameter of this small bowl is 7 inches and the inside diameter $5 \frac{1}{2}$ inches: the height is $I_{4}^{3}$ inches and the ware $\frac{3}{8}$ inch thick. This bowl is reddish-brown in color.

In addition to the incised lines, the potter occasionally added nodes or lugs on the rim and an example of this decoration is shown on plate IV, $c$. The rim of this specimen has concentric incised lines and four nodes which are placed equidistant. The nodes probably represent highly conventionalized heads. The specimen under discussion has an outside diameter of $8 \frac{1}{2}$ inches, an inside diameter of $5 \frac{3}{4}$ inches and stands $2 \frac{3}{4}$ inches high. The ware is $\frac{3}{8}$ inch thick and the vessel is buff-colored.

The most highly decorated form of all is where in addition to the incised lines on the rim, handles of various forms have been added. While only a comparatively small part of the bowl shown on plate $\mathrm{v}, b$, was recovered, this specimen may serve to illustrate the highest development of decoration of the type of vessel under discussion. This specimen has an angular rim upon which incised lines have been carved. Furthermore, nodes have been added to the rim and besides these, a handle representing a conventionalized human head. This head is quite massive and it is permissible to state that another head of the same type must originally have opposed it on the rim. The original diameter of this bowl was 12 inches and its estimated height $4 \frac{1}{2}$ inches. The ware is $\frac{3}{8}$ inch thick and reddish-brown in color.

A critical examination of all vessels with angular rims found in the St. Bernard shell-heaps will reveal the fact that each and every one of them can be classified under one of the ressels described above. The vessels range in size from some with an outside diameter of 3 inches and a height of $I$ inch to the largest with an outside diameter of $16 \frac{1}{2}$ inches and a height of 5 inches. 
Yet another type of bowl was found to occur frequently in the deposits and one of these is shown on plate $\mathrm{v}, c$. This, of course, is the simplest form of round vessel that it is possible for a potter to make. A number of small differences in outline can be found but fundamentally, the bowls are of course the same. The specimen illustrated has a diameter of Io inches and a height of $3 \frac{1}{4}$ inches. The ware is $\frac{3}{8}$ inch thick and is of a gray-brown color. The rim is slightly thicker than the base part of the vessel. The base of this bowl is indented. The inside of this vessel is partly covered with pitch or manjak, and the writer has already mentioned the occurrence of this latter substance in the shell-heaps. He does not believe that in the case of the illustrated vessel this pitch was employed to mend a break in the bowl, as to his mind, in that event the pitch would have probably been applied to the outer surface of the bowl. The writer presumes that the vessel must have been used as a container for the molten pitch. A number of sherds were discovered, however, that had the pitch applied to the inner and to the outer surface, and cases were met with where the vessel showed signs of having been cracked under the pitch-layers. It is permissible therefore to assume that the aborigines were in the habit of mending their cracked vessels with layers of pitch to strengthen the cracked place and to make the vessel liquid-tight.

A slight variation on this type of shallow bowl is shown on plate IV, $d$, where the convex basal part of the vessel is topped by a perpendicular rim. This rim is $\mathrm{I} \frac{1}{2}$ inches high and has been painted red on the in- and on the outside. The body of the bowl is yellow and the entire vessel stands $2 \frac{3}{8}$ inches high. The diameter of the bowl is 6 inches, and the ware is $\frac{1}{4}$ inch thick.

This type of vessel, of which the two specimens described above can be considered typical samples, occurred in large quantities in the middens. Occasionally the rim was thickened or painted and the vessels ranged in size from a diameter of $3 \frac{3}{4}$ inches (the smallest specimen of this kind found) to a diameter of $13 \frac{1}{2}$ inches.

Perhaps the most unusually shaped vessel found in the St. Bernard deposits is the one illustrated on plate $\mathrm{v}, d$. The writer knows of no other vessel like it from the West Indies and considers 

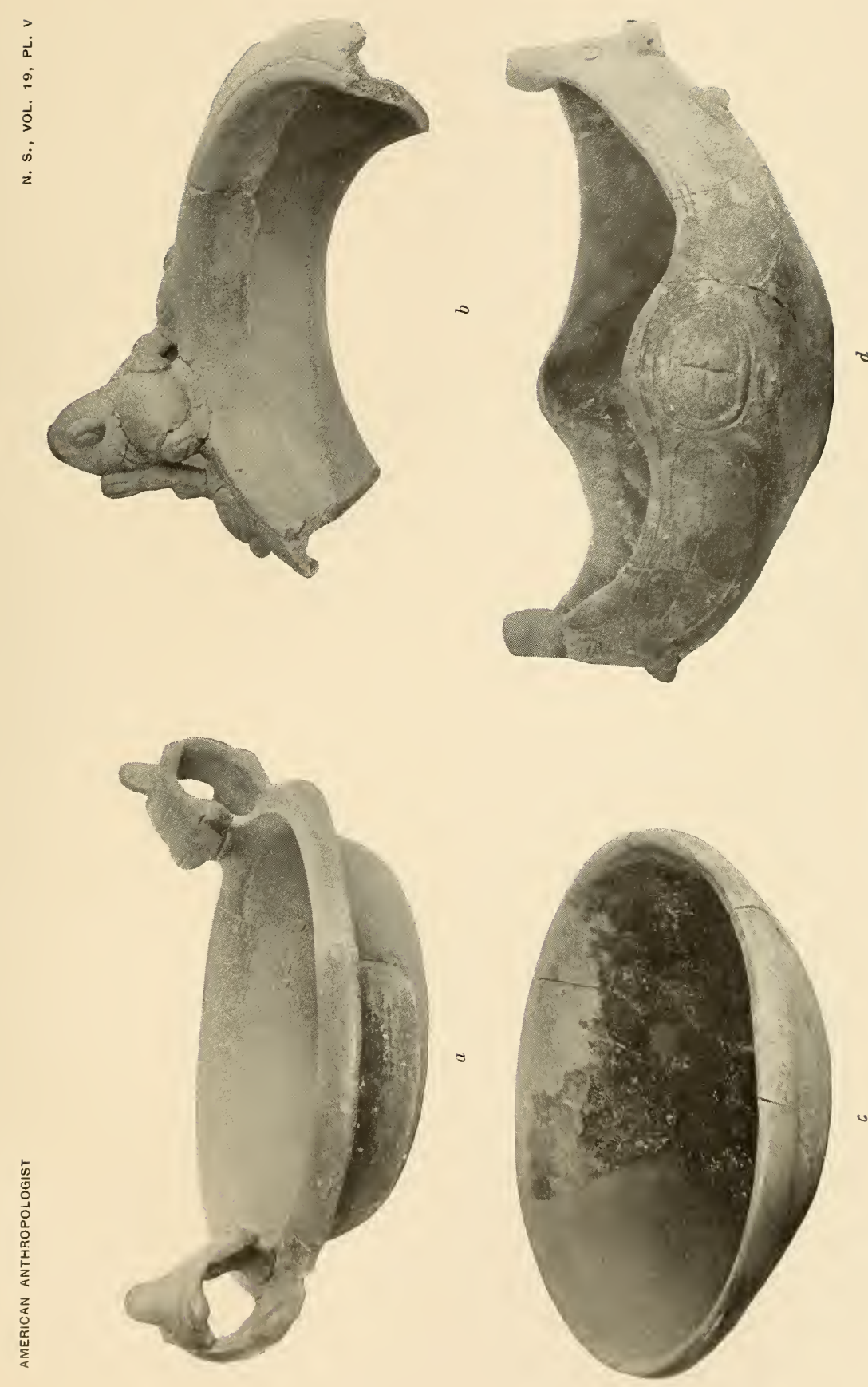

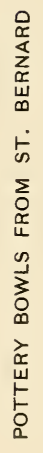

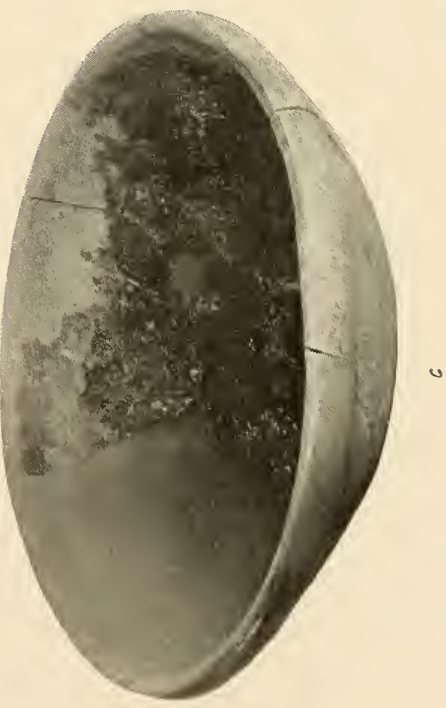



the form unique. The handles of this four-cornered bowl undoubtedly represent the heads of the armadillo, an animal that is frequently found in Trinidad and that is considered a great delicacy by the natives. It may be mentioned that a large number of heads were found in the shell-heaps that represented the armadillo and we judge from this that it was a favorite practice of theaborigines living around Mayaro to thus ornament their pottery vessels. Incised circles ornament the two other terminals of the vessel under discussion and an incised cross can be seen in the one, while the opposite circle contains twelve impressed pits. The bowl is not well made as far as symmetry is concerned. It has a flat base and stands 5 inches high at the rounded terminals. The length of the vessel across the heads is $13 \frac{1}{4}$ inches and it has a short axis of $10 \frac{1}{4}$ inches. The ware is quite thin for such a large vessel, $\frac{1}{4}$ inch. The color of the bowl is buff. Between the heads and the rounded terminals can be seen panels of incised decorations. There is a small lug on either side of the heads and another lug below the incised circle of the rounded terminals.

Another vessel of elaborate pattern is that shown on plate IV, $e$, a fragment of which is also illustrated in situ in plate III, $f$. It is likely that this is one of the so-called turtle-bowls, judging from the shape and design of the incomplete vessel. The head of the turtle can still be seen, but the tail is missing. The four rounded parts of the rim-of which three remain-represent the flippers of the turtle in a conventionalized manner and the outside of these flippers have been decorated with cross-hatched incisions and covered with a dark-red slip of pigment on the in- and on the outside. The rounded parts of the rim are surmounted by a small lug with two incisions. The base of this vessel is flat. The diameter of this bowl is 7 inches and it stands 2 inches high where the head is and $3 \frac{1}{4}$ inches at the highest point of each flipper. The ware is $\frac{1}{4}$ inch thick and the body of the bowl is painted yellow.

On plate IV can be seen another unusual bowl, $f$, of which but a fragment was found. This vessel originally must have been rectangular in shape and has a flat, round base. A grotesque human head serves as handle at the one end and it would be inter- 
esting to know whether the other terminal was provided with a handle and if so, what shape it had. An incised line surrounds the rim on the outside and the rim has been covered with a darkbrown slip of pigment, also on the outside. The grotesque head also has been covered with this dark-brown pigment. The vessel has a width of $6 \frac{1}{2}$ inches and an estimated length of about 8 inches. The height is $2 \frac{1}{2}$ inches and the ware, brown in color, is $\frac{3}{8}$ inch thick.

The small vessel illustrated on plate VI, $a$, is unusual in so far that it reminds us more of the pottery from Santo Domingo and Porto Rico with its incised decoration surrounding the rim in a geometrical pattern. The outline of this vessel was restored from the fragments found and it cannot be determined whether the base was flat or rounded. The largest diameter of this bowl is $4 \frac{3}{4}$ inches and the diameter of the mouth $3 \frac{3}{4}$ inches. The ware is $\frac{3}{8}$ inch thick and the bowl is brown in color.

The flat, discoidal-shaped vessel with the comparatively small mouth illustrated on plate vI, $c$, recalls to our mind the sea-urchin and it may well be that the potter derived the contour of this bowl from the shape of this animal. This vessel is unique in shape as far as the West Indies are concerned and no other fragments of like vessels were found in the St. Bernard deposits. The little bowl stands but $2 \frac{1}{2}$ inches high and its largest diameter is $6 \frac{1}{4}$ inches, while the diameter at the mouth is $3 \frac{1}{2}$ inches. The thickness of the ware, which is brown in color, is $\frac{1}{4}$ inch. An incised line surrounds the mouth of the ressel and forms the only decoration.

The smallest vessel found is the one illustrated on plate vi, $b$, which stands but 2 inches high. It can hardly be supposed that this miniature vessel was intended for a container. The vessel is provided with two small, perforated lugs. An incised line surrounds the rim and two more incised lines the body of the vessel. The ware is brown in color and $\frac{1}{4}$ inch thick. No sherds were found of other vessels of this small size.

A number of double paint-bowl vessels were found in varying sizes and the smallest of these is illustrated in plate vi, $d$. The length of this specimen is $4 \frac{3}{8}$ inches and the height $\mathrm{I} \frac{1}{2}$ inches. The ware is brown in color and $\frac{3}{16}$ inch thick. There is a small lug on each side of the wall separating the two bowls. 


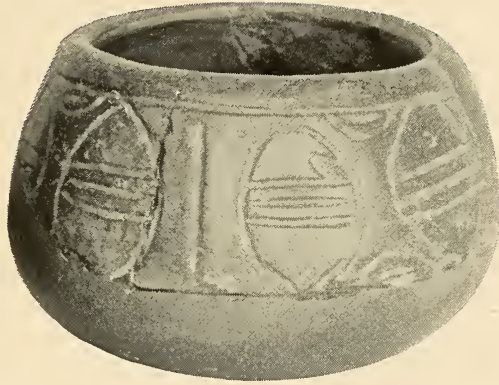

$a$
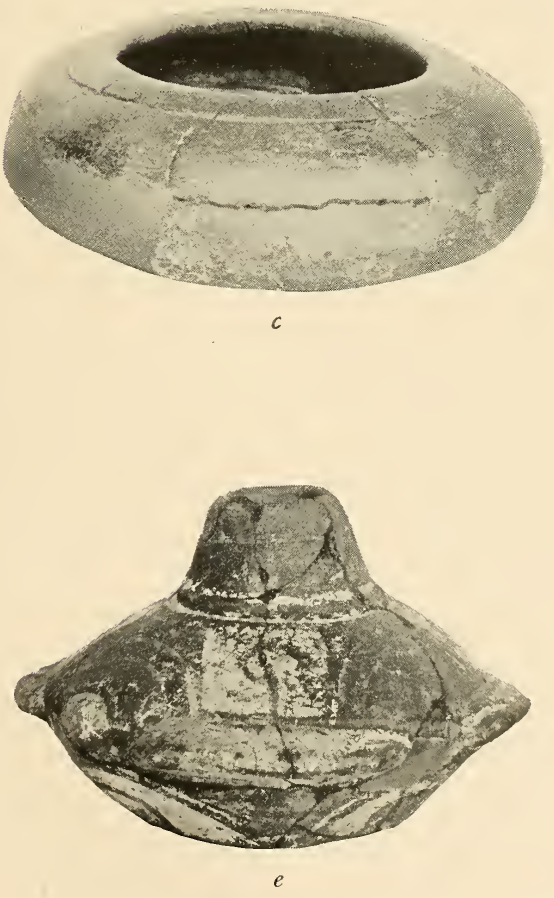

POTTERY OBJECTS FROM ST, BERNARD REFUSE HEAPS 

The small perforated globular object with the incised lines, shown on plate VI, $f$, is either a pottery bead or else was used as a spindle whorl. This is the only specimen of this kind recovered from the Mayaro kitchen middens.

A very large number of pottery heads and handles were excavated in the shell-heaps. These do not differ materially from those illustrated in Dr. Fewkes' paper on the archaeology of 'Trinidad ${ }^{1}$ or from those figured in the writer's paper on the archaeology of Margarita Island. ${ }^{2}$ The heads shown in Dr. Fewkes' paper, from Erin Bay on the south coast of Trinidad are of a slightly coarser manufacture, but resemble the Mayaro specimens in type. It may be noted in this connection that all the St. Bernard pottery was of a more delicate finish than that from Erin Bay and the vessels were not as thick as the vessels collected by Dr. Fewkes. The writer only figures two of the heads collected in the St. Bernard deposits, as these two heads are uncommon in type and are of a variety not previously figured. Specimen $a$, plate viI, is an extremely massive head and larger than the usual types and represents a conventionalized human head. The mouth and the eyes are depicted by incised lines: small impressed pits serve to indicate the nostrils and the ears also have pits to indicate perforations. This specimen stands 4 inches high and is dark-gray in color. Specimen $b$ of plate vil is a flat handle and also represents a conventionalized human head. No other specimen like it was found or is known to the writer, from the West Indies. The head is flanked by large scroll-like ornaments. The forehead is ornamented with crosshatched incisions, as is the back of this handle. The height of this specimen is $3^{\frac{3}{4}}$ inches and it is dark-brown in color.

An extremely large number of spool-shaped pottery rests were found, of varying sizes and two of these objects, $c$ and $d$, are illustrated on plate vir. $c$ has an inside diameter of $2 \frac{5}{8}$ inches and an outside diameter of $4 \frac{1}{4}$ inches and stands $I_{2}^{\frac{1}{2}}$ inches high. The ware is $\frac{3}{8}$ inch thick and is brown in color, covered with a red slip of pigment. $\quad d$ has an inside diameter of $2 \frac{1}{2}$ inches, an outside diam-

${ }^{1}$ Fewkes, J. Walter, op. cit., plates XVI, XVII, XVIII, and Xıx.

${ }^{2}$ Booy, T. de, op. cit., plate II. 
eter of $4 \frac{5}{8}$ inches and stands $2 \frac{1}{2}$ inches high. The ware is $\frac{1}{2}$ inch thick and is brown in color corered with a red slip. Incised lines decorate the body of this rest. On $c$ can be seen single and double nodes which are placed symmetrically around the rim of the object. Some of the pottery rests found were ring- instead of spool-shaped and an astonishing variety of ornamentation was found in the objects of this class.

The writer has purposely left a discussion of the highly decorated painted pottery to the last. It has already been stated that many of the ressels and sherds found showed that a superficial slip or wash of paint had been applied to the ware. This, however, had either been applied after the firing of the clay or else had been ap-

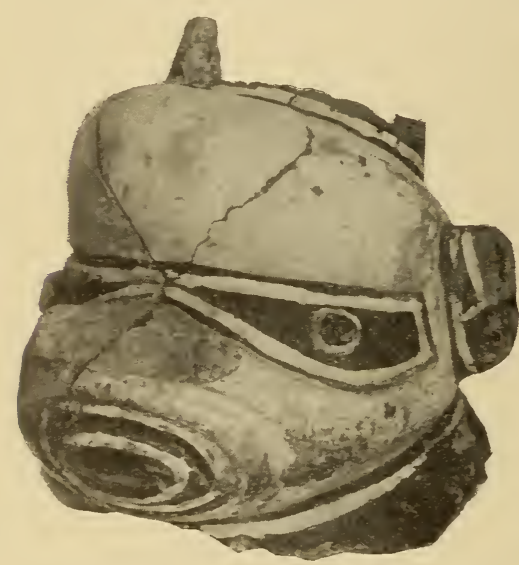

FIG: 62.-Pottery monkey head. plied before the firing and had not become a very substantial part of the ware. A very large number of fragments were found, however, upon which was found a heavy slip of solidly-applied pigment in geometrical designs and these fragments seem to have been subjected to great heat in the firing and are far less brittle than the specimens previously described. Three of these sherds were found on Margarita Island ${ }^{1}$ and these sherds were identical with some eight hundred fragments found in the St. Bernard middens. It must be noted that on no other part of Trinidad have sherds of this class been found to the writer's knowledge. What makes the finding of this kind of pottery all the more interesting to the archaeologist is the fact that it was not possible to reconstruct a single vessel from the sherds found: not only were no sherds of one same vessel found but no two sherds were found even that fitted on to each other. In the object illustrated in fig. 62 , the reader will note the presence of "breaks" in the object, but these breaks

${ }^{1}$ Booy, T. de, op. cit., page 20 , fig. 7 . 

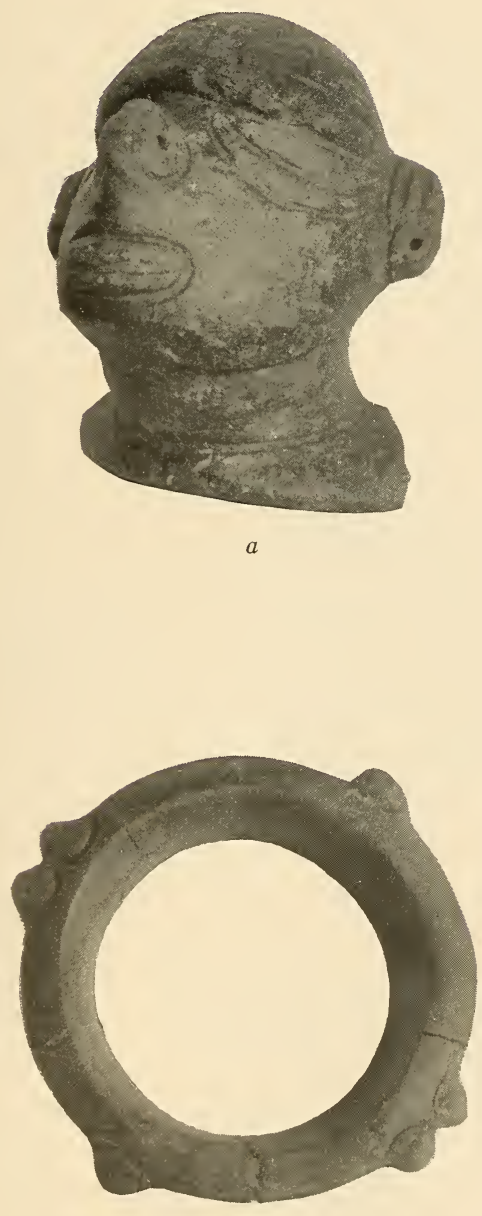
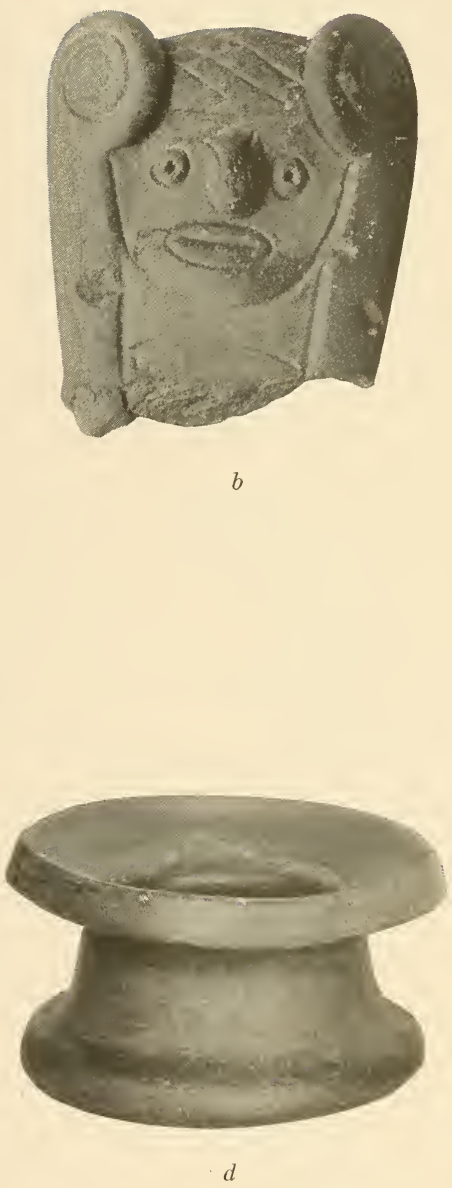

POTTERY HEADS AND POTTERY RESTS FROM ST. BERNARD MIDDENS 


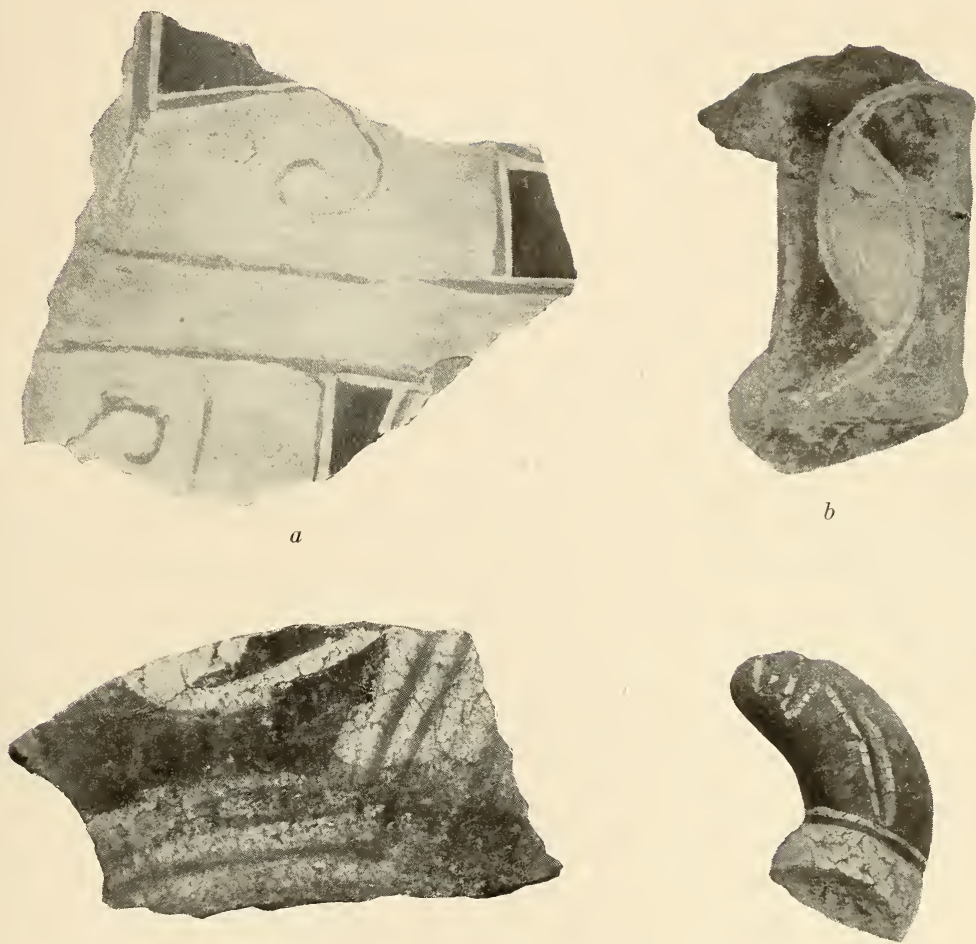

$d$
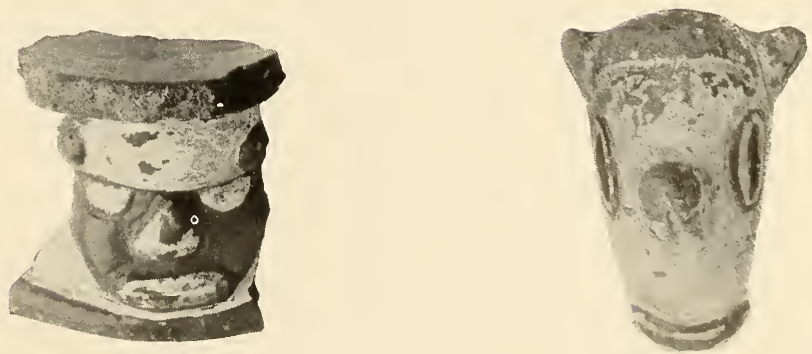

$e$

f

POTSHERDS, LUGS, AND POTTERY HEADS FROM ST. BERNARD MIDDENS 

were the result of the excavation and not of the later matching together of the pieces. It would seem, therefore, as if the aborigines that made this particular class of pottery not only broke the vessels up, but took pains to distribute the resulting fragments over a large area. The writer can offer no explanation for this seemingly meaningless custom.

On plate viII, $a$ and $c$ can be seen two of the sherds under discussion and a superficial examination will convince the reader that these sherds belong to a totally different class of pottery than the kind previously discussed. The ware appears to be far better baked and is not so fragile; the slip is thick and consists of red, brown, yellow, black and white pigment. The designs are applied

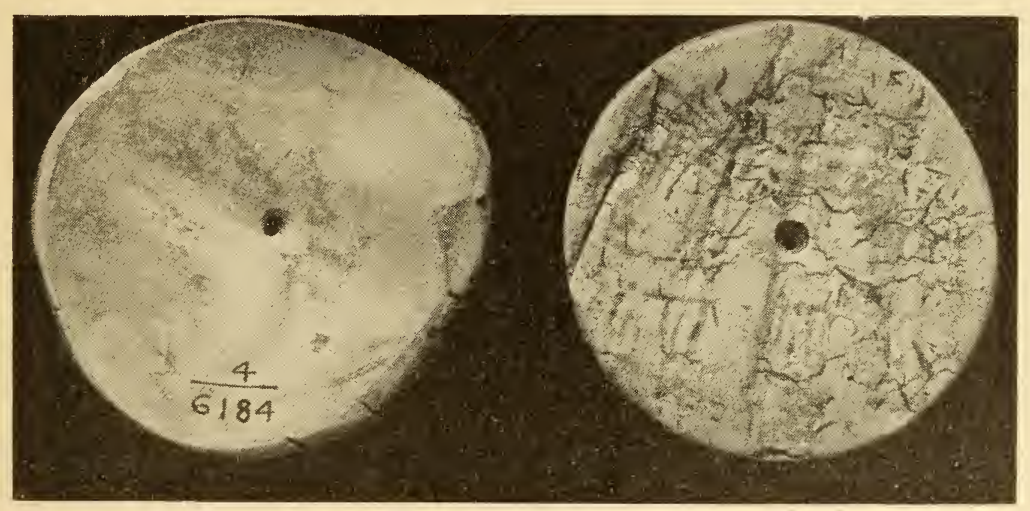

FIG. 63.-Large shell-disks.

in geometrical patterns and it is to be regretted that not enough of one design is left on any one sherd to enable the writer to work it out. The vessels were frequently provided with handles, upon which the potter also placed a painted design. One of these handles is illustrated on plate viII, $b$. Nodes or lugs also were added to the vessels; one of these is shown on plate viII, $d$. Then again some the vessels must have had pottery-heads, of which a grotesque sample is shown in $f$ of the same plate. Another head, $e$, is also shown, which head was part of the base of a vessel.

Judging from a number of the sherds found, some of the vessels served as containers for liquids and had a highly ornamented head 
on top of the vessel proper which served as a spout. The best specimen found is shown in fig. 62 and probably represents a monkey head. Only two colors, white and red, were used to decorate the gray ware of this object, which stands 4 inches high.

The vessel shown on plate vi, $e$, does not belong by rights to the class of pottery described above, although it has received the same painted slip. The ware of this object however is brittle and not well baked. and resembles the ware of the vessels first described in this paper. The decoration is red and white in geometrical design over a brown ware and the writer is inclined to believe that the potter intended this vessel to represent a turtle. Four nodes represent the flippers and the tail is shown. The head has been broken off. This vessel stands 4 inches high and has a main diameter of $5 \frac{1}{2}$ inches. The diameter of the mouth is $I_{4}^{1}$ inches.

A large number of fragments of pottery griddles for the baking of cassava bread were found in the shell-heaps, which fragments

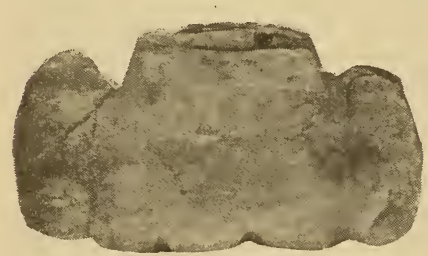

FIG. 64.-Pendant of Amazon stone. did not differ from objects of the same class found throughout the West Indies.

Two large shell-disks were found, shown in fig. 63, which undoubtedly were objects of personal adornment. These disks or gorgets have a diameter of $2 \frac{1}{4}$ inches and are about $\frac{3}{16}$ inch thick.

Yet another pendant ornament is shown in fig. 64. This little object is made of Amazon stone, is $I \frac{5}{8}$ inch long and I inch wide and $\frac{1}{8}$ inch thick.

Museum of the American Indian, Heye foundation, NEW YORK City 

SMITHSONIAN INSTTUTION LIBRARIES

|||||||||||||||||||||||||||||||||||||||||||||||||||||||||||||||

उ 9088016090698 